\title{
カンボジア北東部ラタナキリと 首都プノンペン周辺の酒と発酵食品
}

餅埢と糯米で造る酒は, 「南方草木状」(300 年) に初見され, 「斉民要術」（530～550）には蘆管で飲む粟 米爐酒が紹介されている。以来, 1500 年の歳月を経た現在でも, 中国, ベトナム, ラオス, ミャンマー, インド東部, ブータンにおいて吸酒管で飲む敖穀類酒が造られている。カンボジアについては, 調查が遅れ ていたが, 2004 年小崎の調査によって, カンボジア東北部に吸酒管壶酒があることが明らかとなった。こ の貴重な調查結果を報告していただいた。

\section{小崎道雄}

\section{I 、はじめに}

東南アジアの発酵食品について，これまで島嶼部の フィリピンの米酒タプイ (Tapuy) ${ }^{1,2,3)}$, 甘鷹酒バシ $(\mathrm{Basi})^{4)}$, 米パンプト (Puto) ${ }^{5)}$ などから, インドネ シアのかび納豆テンペ (Tempe $)^{6)}$, 豆豉タウチョ (Tauco)，ごま発酵団子チャブク (Cabuk) $)^{7)}$ な゙に ついて,また大陸部ではミャンマーの納豆ぺポ (Pepo), 発酵茶ラペソー (Lapeso), 塩辛ガピ (Ngapi), 米発酵麺モヒンカ (Mohingka) および夕 イの納豆卜ゥアナオ (Toa nao), 発酵茶ミャン (Miang), 米酒オウ $(\mathrm{Ou})$, 魚醬ナンプラ (Nampla）など, ラオスの納豆トゥアシ (Toasi), 米蒸 留酒ラオラオ $(\text { Lao lao })^{8)}$, ベトナムの魚醬ニオクマ ム (Nuoc mam), 米酒ルオウカン (Ruau can $)^{9)}$, 甘 蔴酒アビエ夕タウ (Avieta taw) などに関して調査 を進め，それぞれについて報告してきた。

カンボジアについても, 2002 年の文部省科学研究 費補助金基礎研究によって, 東南アジア最大の湖トン レサップ湖 (Tonle sab) ${ }^{10)}$, 西北のアンコール (Angkor), シェムリアップ (Siem reap) ${ }^{10)}$ 周辺, ま た東南部の湖畔からトレンサップ川沿いの村々, およ びプノンペン (Phnom penh) から南部海岸にかけて の町村に住むチャム (Cham) とクメール (Khmer) 両族の酒類と発酵食品を調べる事ができた。

その調査の結果は, まとめてトンレサップ湖西北部
とプノンペン南部の塩辛プラホック $(\text { Pra hoc })^{10)}$ や 楖子酒トクタノットチョア (Toekthanot chour) ${ }^{14)}$ などの数編に緾めて報告した。

カンボジアは周知のように 1887 年以来フランスの 支配下にあったが, 第二次世界大戦以降, 数回の政治 的抗争を繰り返し，1953 年に至って完全な独立国と なった。しかしポルポト政権の弾圧に遇って, 内紛は なかなか治まらなかった。ようやく 1993 年になって 新しいカンボジア王国が誕生し今日に至っている。従 って長い間の抗争によって壊滅的に破壊された国民の 生活も一応静穏な状態に復帰してきた。

ただこのような状況にあっても, 地方の農家の暮ら しは政治や経済の変動に関係なく, 古くからの生活を 習慣的に固守しながら守られてきたようである。した がって, 農村の食生活, なかでも発酵食品や醸造食品 を例にとっても, これら食品の長い期間の変化は, 周 囲の流れによって, 少しずつ変容しながらも伝統色は 失っていなかったと調べながら考えられた。農家レべ ルで造られる漬物や納豆がそうである。

2004 年 5 月には首都プノンペン近郊の農家および 東北部のラタナキリ（Rattanakiri）州の州都バンル ン (Bang alung) 周辺, およびサン川沿いのベンサ イ（Voen Sai またはVirachey）村と其処に至るムラ チェイ高原の農家を調べた。

本報では, カンボジア北東部ラタナキリ周辺の米酒 とその蒸留酒や納豆について, また首都プノンペン付

Alcohol Beverages and Fermented Foods of Ratanak Kiri, in Northeast Cambodia Michio Kozaki (Emeritus Professor Tokyo University of Agriculture) 


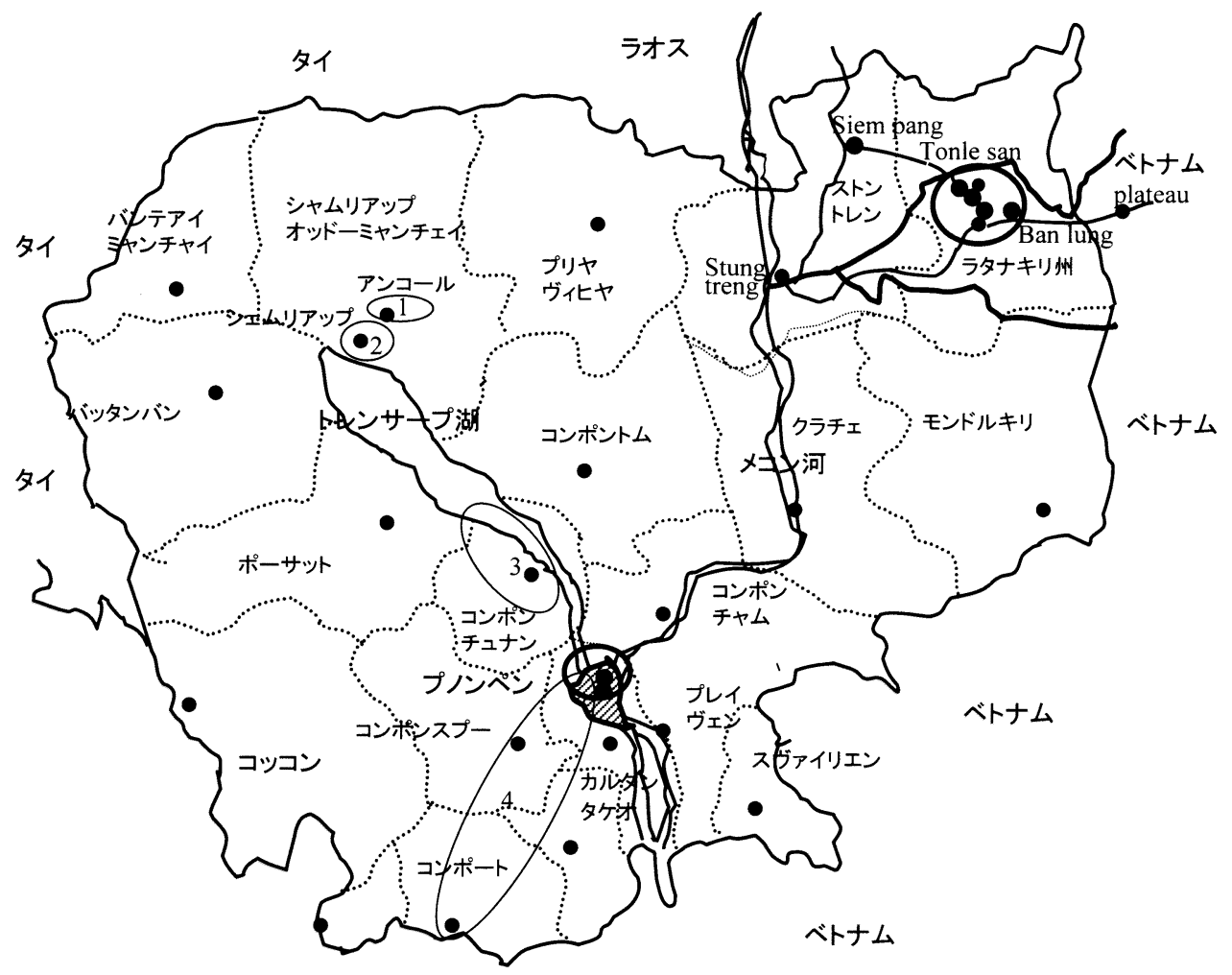

第 1 図 カンボジアでの調査地域

$\bigcirc 2002$ 年文部省基盤研究での訪問地 $\bigcirc 2004$ 年の調查地

近と南部の発酵食品（納豆, 漬物, 豆豉など）につい て記載した。

\section{II．豆鼓と納豆および漬物}

東南アジアの大豆発酵食品のうち, 納豆はネパール から東アジア，東南アジアに至る地域に分布している。 この分布の広がりに関して吉田よし子氏の納豆分布 図 ${ }^{11)}$ が参考になる。しかし, カンボジアとべトナム は白紙のまま処理されている。1900 年前半には国交 がなく調査不能であったからであろう。

1999 年および 2002 年のベトナムについて行った 2 回の調査によれば, ベトナム中部のフエ (Hue), ダ ナン (Danang), ホイアン (Hoian) から南部のダラ ット (Dalat), ニャチャン (Nha trang), ホーチミ ン（Ho chi minh）に掛けての一帯は, マーケットを 覗いてもなかなか納豆は見当たらなかった。

ホーチミン大学のホー教授 (Dr. Pham Than Ho, 食品加工学）およびトク教授（Dr. Tran Linh Thuoc,
食品微生物学) 両名は, 南部ベトナムには「納豆はな い」と明言しているから確かであろう。しかし, ベト ナム北部の雲南（中国）に接するラオカイ（Lao Cai), ライチョウ (Lai chau), バクハー (Bacha) のマーケットでは, 雲南の影響を受けて生の納豆や納 豆板が各地で売られていた。

また，中国国境から離れた夕イのバンコクからミャ ンマーのマンダレー, ヤンゴンでも日常の食品として 納豆は売られている。したがって地理的に納豆を持っ ているタイと, 造っていないとされるべトナム南部に 挟まれているカンボジアが, 納豆を造り且つ食べる習 慣を持っているか否かを確かめる事は意味があろう。

（1）チャロイチャバ村 (chroy chanva)：蠅の飛 び交うクメール族の農家

2004 年 5 月の調查は, プノンペンの北のトレンサ ップ川沿いの村から始めた。緑の濃い雑木林の中に佇 むクメール族とチャム族の居住するチャロイチャバ村 である。チャム族は多くは川筋に住み漁業を営んでい 
た。最初に訪れたクメール族の農家は, 豚と鵎を飼つ ていたが, 酒と野菜の漬物を造っている部屋は蠅が飛 び交っていて全く污い。片隅で米酒の蒸留粕へ野菜屑 などを入れて豚の餌にしていた。

また高菜に似た野菜の漬物は, 数日漬け込んで，仲 買を通し市販するという。浸けてある数個の漬物容器 は壁際に並べてあった。

（2）チャロイチャバ村：中国系移民オーホウ氏の 家

この農家から車で 10 分程の所に納豆, 漬物（主に 干し大根と野菜の漬物）などを手広く製造しているオ 一ホウ (mr. Ou Hour, 吳華) 氏の家があった。

この家では, 下記のように味噌に近い大豆発酵食品 を製造して抢り，先ず納豆の作り方そっくりに発酵さ せた後, 塩水を加えていた。無塩発酵の系を引く納豆 ではなく，寧ろ「豆豉」の製法と類似した製品で，村 ではシアン（またはシェン, Sian）と呼んでいた。 ただし発醭期間は短く数日で，製品は市販される。ま た，加塩前の納豆は飯と一緒に食べると言う。

シアン製造には小粒大豆が大粒より質のよい製品が えられるから, 何処のシアンを造る農家でも小粒大豆 (和名, ツルマメまたはノマメ, Glycine ussuriensis）を原料としていた。

精選小粒大豆 $\rightarrow$ 洗浄 - 者熟 $\rightarrow$ 平笑水切り $\rightarrow$ 室温 発酵（2 夜～4 夜) $* \rightarrow$ 干す (1 日) $\rightarrow$ 塩水添加 $\rightarrow$ 攪汼 (2 回/日) $\rightarrow$ 熟成 $\rightarrow$ 豆鼓（シアン）

第 2 図 オーホウ氏の豆豉（シアン）の製法 注*ここまでの工程で無塩の糸引納豆が出来ている

大豆は洗浄後浸漬せず，指で潰れるくらい柔らかく 煮熟する。小粒だから水を吸って 2 倍位の大きさにな り，短時間の煮熟で柔らかくなる。

煮上がったら布を敷いた竹製の平笑（カチレン， Kachren）に移し，2 夜から冬は 4 夜の間湿度のある 場所に置き発酵させ，その後 1 日間天日で干すと納豆 ができあがる。しかし，チロイチャバ村周辺では，干 した後 $20 \%$ 塩水 $24 \mathrm{~L}$ を大豆 $10 \mathrm{~kg}$ に対して加え, 1 日 2 回攪拌し乍ら暫く熟成させて豆豉を作り上げてい た。

この加塩の前の生の納豆は, 僅かに古草菌（納豆 菌）の特徵である㱀のある死白色膜と特有の臭いがあ

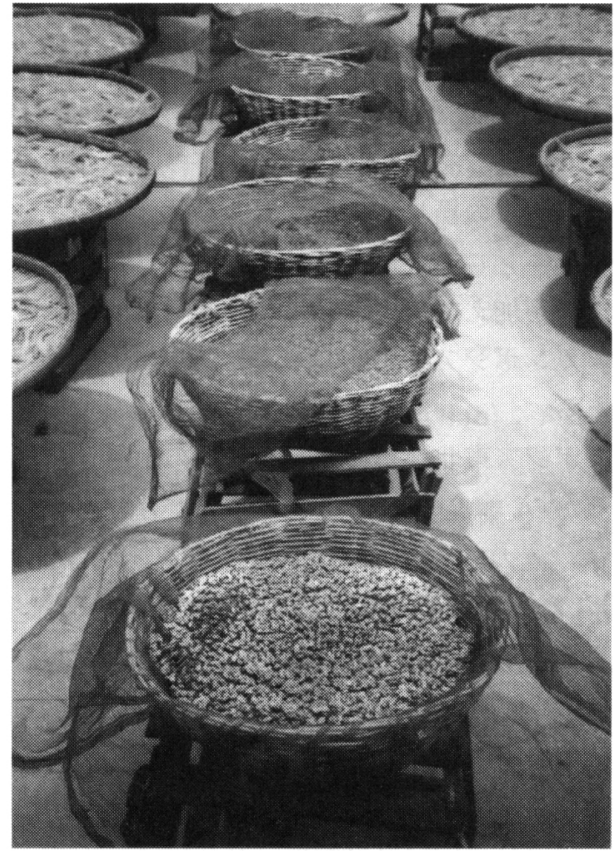

写真 1 納豆発酵後 1 日間天日に干す。 このあと，塩水を加え豆豉とする。 (トンレサップの川沿い村)

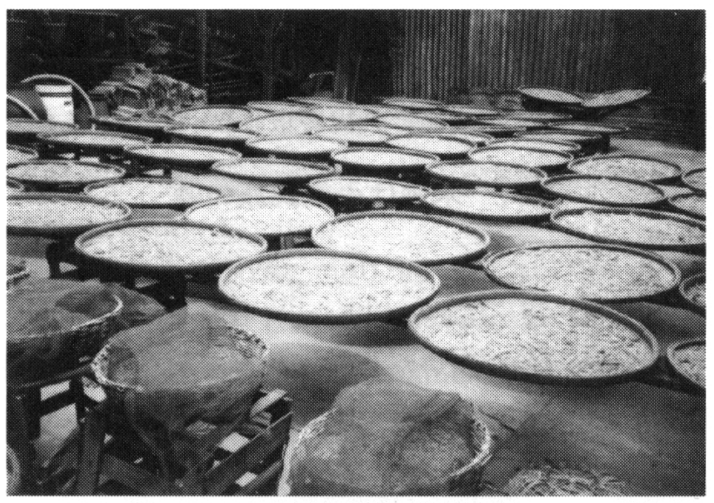

写真 2 切り干し大根 写真 1 と同じ農家

り, 短い粘質の系を引いていた。

オーホウ氏の家では中華料理店用の大根の切干しと 薄塩沢庵も作っていた。テニスコート 2 3 面位の広 場には細切りした大根を並べて干してあったし, また 屋内には野菜の塩漬けの瓶も並べてあった。

\section{（3）バンルン町：タナキリ州の州都の露店市場}

此れに対して, バンルン市の露店市場では, 生の納 豆を香辛料と砂糖で調味した糸引納豆が売られていた。 バンルン町の婦人は, 発酵の終わった納豆には塩水を 
加えて全部豆豉にし, 無塩の納豆は食べないと手を振 り乍ら否定した。

納豆の食べ方であるが，2005 年 3 月ミャンマー北 部のレドロードを訪ねた時, その町の人達の納豆の食 べ方は, 間食の摂り方のようであった。それは, 生の 納豆に, ニンニク, 青唐辛子, ピーナッツ, カシュー ナッツ等を加えて, 大葉に包んで菓子のように食べて いた。カンボジア東北部の人達の摂り方に似ているよ うである。

カンボジア東北部農村でも, 無塩の糸引き納豆は存 在するから, カンボジア全域に納豆が存在すると考え てよい。

\section{（4） カンボジアの市場の漬物}

ところでプノンペン周辺, トレンサップ湖北西のシ エムリアップ周辺㧍よびラタナキリ州のバンルン周辺 のマーケットでは, 漬物の売り場は案外に少ないよう に見受けられた。タイのバンコク, チェンマイ, コン ケン, ジャワ島のジャカルタ, ヨクジャカルタ, ルソ ン島のマニラ，バギオなどのマーケットに比較すると， 漬物の売り場の数も並べられた品数も少ないようであ る。漬物の少ないのに比べ生鮮野菜や果実類は, 多く の種類が山積みされて売られていた。圧倒的な果物の 陰で少なく見えるのであろうか。あるいは生鮮野菜が 常にあるから，漬物を学桯要求しないのであろうか。

\section{III . 米酒は少数民族の酒}

ラオスのファイサイ (Huai xay) からタイ最北端 のチェンコーン (Cheng khong), バンコクを経由し て, プノンペンに着いたのは 2004 年 5 日 20 日の真昼 であった。早速, 空港近くの蘇利亜大餐廳で昼食をと

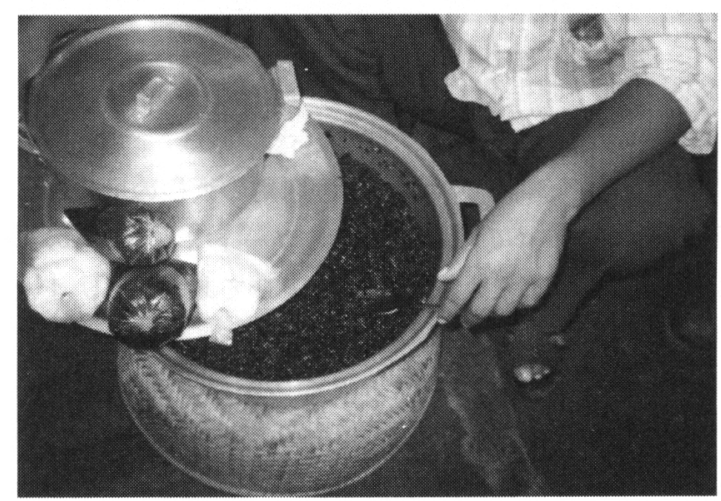

写真 3 黒米の甘酒 プノンペン郊外
つたが，カンボジアでは甘酒を飲むからと赤紫米の甘 酒の濃いものを勧められた。

周知のことだが, 中国の雲南省では米から蒸留酒を よく造っているが, 隣接するミャンマー, ラオス, べ トナムの北部地域の米由来の醸造酒は, 2005 年のミ ヤンマー, 2004 年のラオスとミャンマーの調査の結 果, 現在ほとんど消滅し, 蒸留酒製造に移行していた。

伝統を守る傾向の強いこの三国の北部地域の少数民 族であっても, 古くから竹管などで飲む吸管酒は, 時 を追って次第に姿を消し, 酒造りは醸造酒からさらに 蒸留酒へ変わっていた。

カンボジアもインドシナ半島の南部にあり, 雲南か ら約 $1200 \mathrm{~km}$ 離れているが, 中国南部や雲南の食文 化の影響を受けている。

\section{(1) プノンペン近郊の酒}

(1) プノンペンの露店市場で見られる黒米甘酒

空港近くのレストランで見た先述の赤紫米の甘酒の 他に, 町の露店では白や赤の甘酒が並べて売られてい た。

(2) チロイチャバ村の農家の蒸留酒（スラソー, Sura sou）：蠅の飛び交う農家

先述の農家では, スラソーの製造は熱心のようで, 蒸留のための米酒醪の入った畺が $3 \sim 4$ 個あり, 数年 前に設置した蒸留器は, 北部ラオスと同型の東方型の 外取り式 ${ }^{15)}$ で, 数日に一度蒸留してスラソーを製造 するそうである。

(3) パンテデック村とその隣村の蒸留酒

プノンペン近郊では, 米酒の粐殼吸管酒（スラピア ン, Sura peang）は 2002 年の調査, 2004 年の調査で

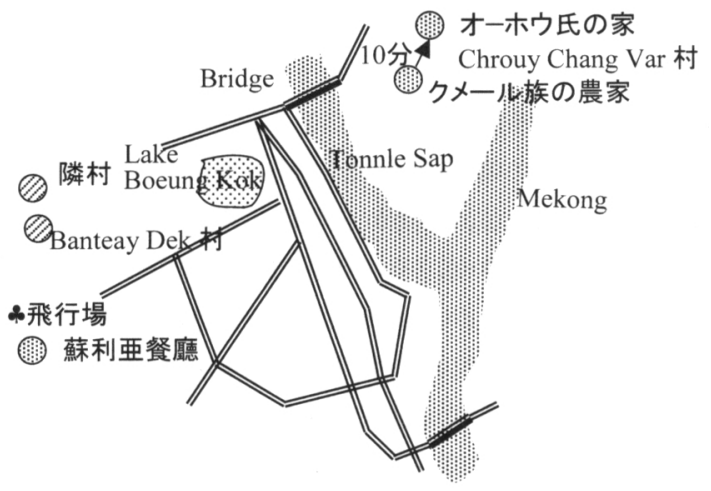

第 3 図 プノンペン近郊の調查地 2002,2004 年調查 2004 年調查 


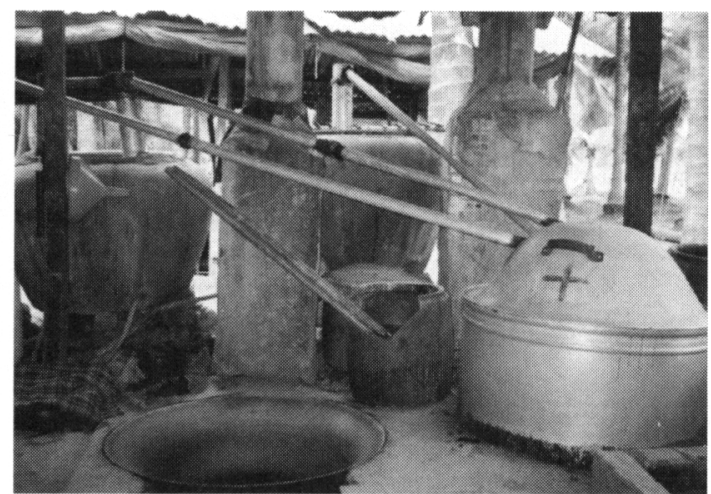

写真 4 パンテデック村の蒸留器

も既に見当たらず，クメール族の多いパンテデック村 (Banteay dek, プノンペンの西) や同じ族の住む隣 村の農家では, 素朴な数個の東方型外取り式蒸留器に よって，スラソーが造られていた。

\section{（2）バンルーン近郊の酒}

森の中にあるバンルーン（Ban lung）町は，人口 1.7 万人足らずの小さな町で, 素朴な風景はラタナキ リ州の伝統的な発酵食品調査に, 強い期待がもたれた。 ラタナキリ州は面積の大半が山岳地帯である。総人 口 9.4 万人の内, クルン族 (Krueng), トンプン族 (Tompun) が $76 \%$ を占め, 次いでジャライ族 (Charay), プノン族 (Punon), カチョ族 (Kachok), 力チャ族 (Kacaet), プラウ族 (Prov) およ びロン族（Lon）の6 少数民族が占めている。この内, クルン族とトンプン族の 2 族は酒造りに熱心であるが, ジャライ族はそれ程でもないそうである。これらの少 数民族は, 殆ど粐殼吸管酒（スラピアン）を期待通り に醸造し，スラソーは持っていないように見受けられ

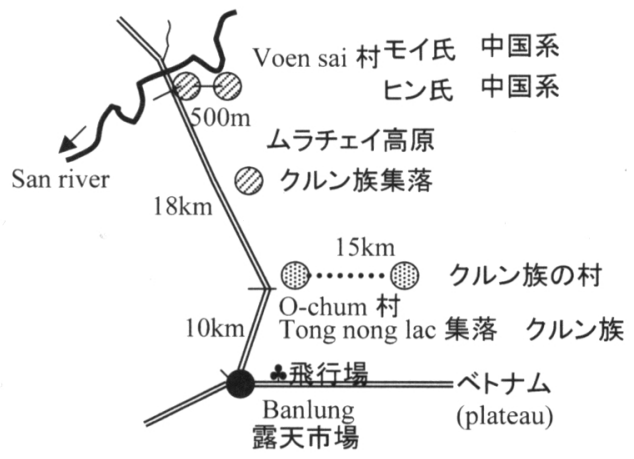

第 4 図 バンルン近郊の調査地 2004 年調查@1 日目留2 日目
た。

ラタナキリ州では，オーチョム，ベンサイ（または， ビラチャイ Vira chey) など 5 箇所を調査したが, べ ンサイ村 1 ケ所だけは東方型外取り式の古い蒸留器を 置いて, スラソーを造り, その他の地域では, 昼にも 拘わらず，4〜 5 名の農民達が酒盇を囲み，竹管を差 し込んで米酒を飲んでいた。ここには，未だ米酒の粐 殸吸管酒が残っていたのである。

(1) トンノラック集落 (Tong nong lac) : クルン族 の酒スラピアン

バンルンの町に着いた時には，既に真㡺を過ぎてい たので，そのまま迎えのトラックに乗り込み， $10 \mathrm{~km}$ 北へ走る。最初の調查地クルン族のオーチョム村 $(\mathrm{O}$ -chum）の隣の集落，トンノラック（Tong nong lac）を訪ねた。この集落は，周囲を丸太の柵で囲ま れ，入口は表と裏にある柵作りの門 2 箇所だけであり， 柵内には 20 軒ばかりの高床平屋が疎らに建っていた。 若し, 死人が出たり, 何か問題が起きたりしたら柵門 に印が置かれ, 許可なく入れないそうである。もし掟 を破るとその重さによって, 村の神様に詫びるため, 豚数頭または牛などで支払わなければならないと言う。 幸い筆者は案内人と共に, 簡単にトンノラック集落に 入ることを許された。このトンノラック集落の 20 軒 のうち, 酒を造っていたのは 1 軒のみであった。その 農家の米酒の粐殼吸管酒スラピアンの製法は次のよう であった。

粳米 $15 \mathrm{~kg}$ を飯同様に炊き，糖化と発酵を兼ねた発 酵種として粗く粉にした木の根 $5 \mathrm{~kg}$ を加える。木の 根は, 甘い根のチュアム (Tyuamung), 苦味をもつ 根のルンダ (Lundang), それに辛味のあるロンブラ

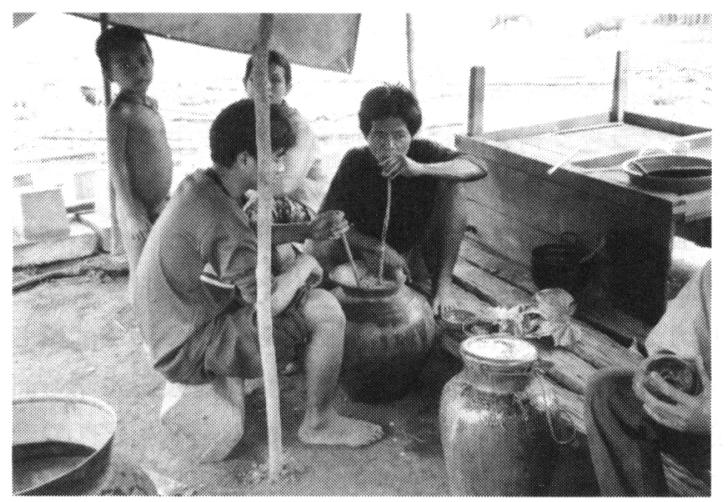

写真 5 粐款米酒を竹またはビニール管で飲む 


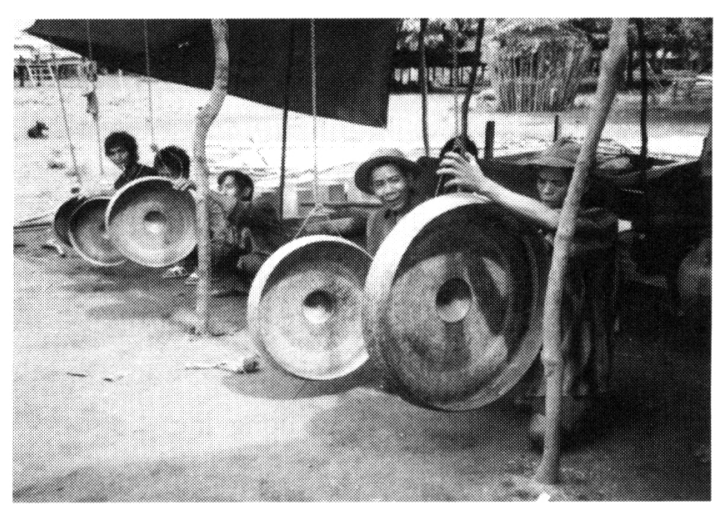

写真 6 粐殼米酒を飲む集りのため鉦をたたく。 このうしろに酒壷が 5 ツばかり置いてある。

ン (Long broung) の 3 種類である。調査の時は，木 の根の現物はなく，既に粉の状態で貯えてあって，三 種の混合比は不明である。

木の根の粗粉を混ぜた飯は，発酵を進めるため広口 の陶器壶に入れて置く。1 週間で飲めるようになるが, 長く貯蔵すれば更に旨くなると言う。発酵している西 の醪は酸味のある酒であった。

集落の広場では，4～5 名の人達が，筵の上に酒盇 を 3〜4 個置いて竹管を持ち酒盛りを始めていた。何 時もの酒を飲み団欒する場所のようである（写真 5)。

クルン族の人達は, よく酒を飲むが, 土地の神, 家 の神などの神々に必ず供えてから飲み始める。皆で飲 む場合は先ず写真のように鉦をたたいて呼び集める (写真 6)。飲む順番は厳格で無いが, 年令にしたがい, 女性は酒を造り，男性は飲む。プノン族は約束の時， 互いに血を混ぜて飲む習わしを持っていると言う。

(2) オーチョム村から東へ $15 \mathrm{~km}$ 程のクルン族の 村：クルン族の酒スラピアン

粐殼吸管酒スラピアンを造っていた。30 年前迄は, トンノラック村と同様発酵種として木の根を使用して いたが，現在は餅麹を使用していた。

製法であるが，先ず粐米を干し杵搗き臼でついて粐 款を剥ぎ，米と粐殼に分ける。米と粐殼を容量比で 1：1の割合で混合して適当に水を撒いて蒸す。蒸し 上がった混合物を 6〜 7 時間から半日程天日に干し， 餅贅を米 $1 \mathrm{~kg}$ に対して 3 個砕いて加える（写真 7)。 餅銤は，マーケットで購入したベトナム製の餅瞵（直 径約 $2 \mathrm{~cm}$ ）である。餅耧を加えた蒸した米，粐款の

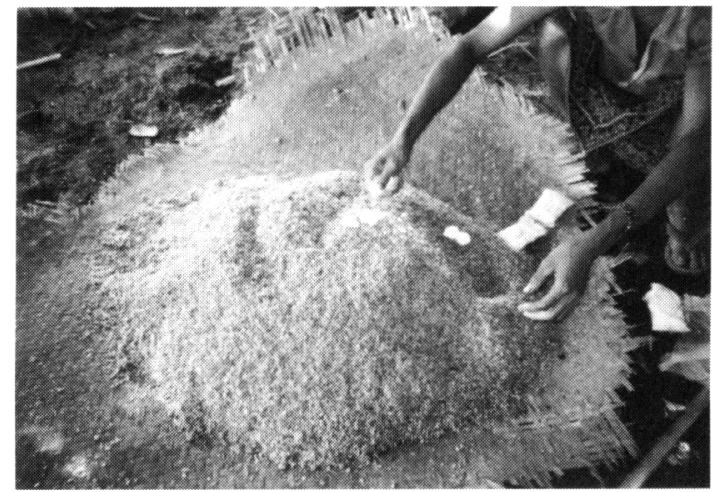

写真 7 米と粐殼を混合して蒸し天日で干したものに 餅麦匊を撒布する。

混合物は畫に入れ蓋をして, その儘室内に置く。1 週 間後に飲めるような酒になる。飲む途中, 竹管で吸い 難くなるとヤカンで水を差して飲む。水を加えてのみ 続けるのは, ベトナム，タイ，フィリピンでも同じで ある。

(3) ムラチャイ高原の集落：クルン族の酒

次ぎの日オーチョム村から更に北西に 15〜20 km 程のサン川の畔にあるベンサイ村付近の発酵食品を調 ベた。バンルンから $40 \mathrm{~km}$ 位の距離である。バンル ンを出て暫くは火炎樹並木の四車線道を走って行くが, すぐに森の曲折した凸凹道に変わった。昨夜の雨で大 きな水貯まりが無数にあって, トラックはまるで小舟 のように摇れる。車の空は跳水上がる泥の飛沫でしば しば見えなくなった。

焼き畑が森の切れ目切れ目に連続して広がっていた。 付近のクルン族は焼き畑で生計を立てているようであ り, 焼き畑には野菜の栽培とカシュウの植林が見られ た。バンルンからベンサイ一帯はカシュウナッツの産 地として有名な地域だそうである。

ムラチョイ高原の森の間伐された斜面にクルン族の 高床平屋の家が 10 軒ばかり見えた。全く人の姿は見 えなかったが, 細い路地を入ったら農家の土間で 50 才前後の農婦がカシューナッツを選別していた。土間 の片隅には布を被せた発酵中の 5 個の酒壹が置いてあ った。醪を見せて貪ったら, 醪の表面に空気との接触 面を広くするための穴が 3〜4箇所あけてあった（写 真 8)。仕込み 2 日目の醪で, 明日別の䒼に移し換え る予定だそうである。

(4) ベンサイ村：中国系民族の蒸留酒スラソー 


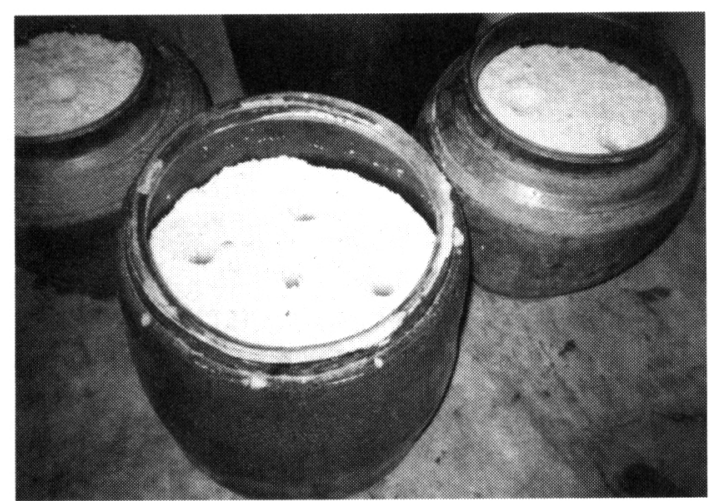

写真 8 醪発酵には穴があけてある。

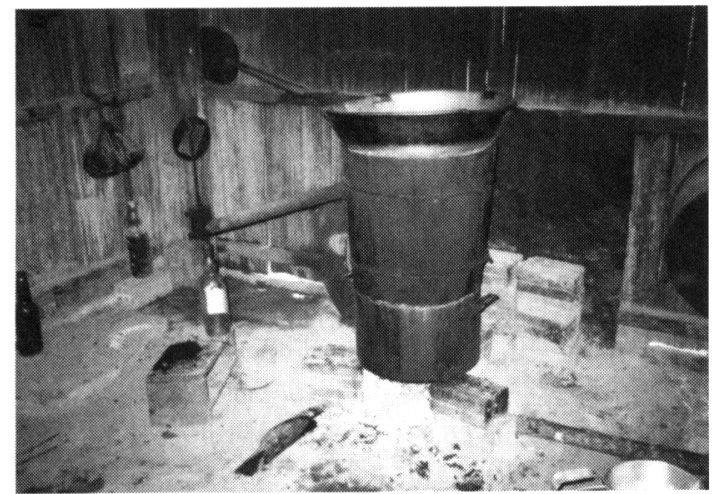

写真 9 東方型, 外取り型の素朴な蒸留器（バンルン 郊外) 流出竹管が下がっている。（お去らく 醪の突沸液が入りこむのではないだろうか)

焼き畑の続くムラチェイ高原を横切って $18 \mathrm{~km}$ ほ ど悪路を進むと，中国系，ラオ族，クルン族の人達が 暮らすベンサイ村がある。中国系の人達は, 中国から の移民で，既に 4 又は 5 代続いた子孫になっていた。 この村では 50 軒（300 名）のうち，6 軒が米からの蒸 留酒（スラソー）を造っていた。中国系の部落は，酒 造りに熱心で, それも総べて蒸留酒であった（写真 9)。発酵は, パアプ ( $\mathrm{Pa} \quad \mathrm{up})$, 発酵したものをカチ (Kachi) と呼ぶそうである。

酒造りを調べさせて苜ったモイ氏も，広東省から移 住し 4 代目の中国系の人であった。モイ氏の家の蒸留 酒の製造法は, 下記の模式図の上うであり, 雲南の米 酒蒸留酒の製法と基本的に類似していて，このベンサ イ村の焼酎はすべて村で消費されるそうである。

また，モイ氏宅から $500 \mathrm{~m}$ 位離れた中国系のヒン 氏も，米からの蒸留酒を造っていた。モイ氏の製法と
違う点は, 一次発酵を 5 日, 加水は $15 \mathrm{~L} / 15 \mathrm{~kg}$ 米で モイ氏より $5 \mathrm{~L}$ 多く, また二次発酵も 10 日間と発醳 時間が長い事であった。香味とも燒酎のようであった。

粳米（ジャポニカ型） $\rightarrow$ 炊飯 $\rightarrow$ 冷却 $\rightarrow$ 餅趜撒布 $\rightarrow$ 壱，固体発醉 (一次発酵，3日間） $\rightarrow$ 加水 $(10 \mathrm{~L} / 5 \mathrm{~kg}$ 米) $\rightarrow$ 盇発酵 (二次発酵, 6 日間) ）米酒(この儘でも飲める, 通常は熟成させ る） $\rightarrow$ 蒸留 $\rightarrow$ スソー

第 5 図 モイ氏の蒸留酒（スラソー）の製造模式図

\section{IV . おわりに}

カンボジアの首都プノンペン周辺と南部, トレンサ ップ北西のシェムリアップ一帯扔よび北東部のラタナ キリ州バンルンからベンサイの広い地域の酒類と発酵 食品を, 2002 年 2 月 (プノンペン周辺, トレンサッ プ北西地域）抒よび 2004 年 5 月（プノンペン周辺お よびラタナキリ州）に通算 4 週間の短期間であったが， 調べることができた。

プノンペン，シェムリアップの一帯はカンボジア人 口の $80 \%$ 以上を占める主要民族クメール人が居住し, 多くは稲作を中心とした農業に従事している地域であ る。一方ラタナキリ州は北をラオス，東はベトナムに 国境を接する標高 300 1500 m の山岳地帯で，住民 の $76 \%$ 占めるクルン族，トンプン族と少数民族が

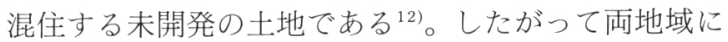
はそれぞれ異なった古くからの発酵食品や伝統酒の文 化が生きずいて存在していると期待した。特に発酵食 品のなかでは納豆を食べる習慣を持っているか否かに ついて，また酒類に関しては米酒とその蒸留酒につい て興味があった。

そうしてプノンペン周辺およびバンルン付近のマー ケットを見たり，土地の人に聞いた結果，プノンペン には生の納豆も乾燥後潰して煎餅状にした納豆が売ら れていたし，家庭では飯と一緒に食べるそうである。

東北部のラタナキリ州も南部にプノンペン一帯と同 様に，生納豆と加塩豆豉が見掛けられたが豆豉の方が 多い。後者は保蔵出来るから多量に造られるのである う。豆豉は無塩（淡豆豉, 納豆など）と加塩（㽣豆豉, 味噌類）および水豆豉と干豆豉に分けられているが13), 
カンボジアでは全ての豆豉が作られているから，この 国全体に納豆は浸透していると考えてよい。吉田よし 子氏の東南アジアに扔ける納豆の地図に, カンボジア は納豆を造る地域として加えられる。

米酒に関しては 2002 年 2 月, プノンペン大学を訪 ねた後，プノンペン市のベンサラン (Boeng Salang) 地区にある中国系の米焼酎店と南部のプノンペン周辺 のクメール族の農家を調べ, 2004 年 5 月にはプノン ペン周辺と東北部ラタナキリ州のバルン町一帯のクル ン族や中国系の農家などの少数民族の持つ伝統的な米 由来の酒を調べた。

プノンペン近郊では醸造酒の醸造は姿を消し, 蒸留 酒に移行していた。一方東北地方のラタナキリ州バン ルン町近郊の農家では，未だ粐款吸管酒を造っていた。 またバンルンの北北東 $20 \mathrm{~km}$ にるラバン (Labang) には数年前まで口噛み酒もあったらしい。 また発酵種として数年前迄草木や植物の根を用いてい たが，現在では市販の餅鍻を使用している。タイ，ラ オス, ベトナムでは餅麹を粉末にして小さなポリ袋に 入れて売られているが，バンルンのマーケットでは， 往年のタイ，ラオスのマーケットのように餅敖のバラ 売りであった。

カンボジア東北部は，伝統的な食品製造法が残って いると考えられる。例えば，発酵種を数年前まで野生 の植物に求めていたり, 餅趜に変わっても自家製であ ったり，また粐殸殺菌も米と共に蒸すことによって行 う古い方式が残っている。東北部で見た粐款吸管酒は 粐殼の量も，他に比べて多くしかも煮熟も米と混ぜて 行うなど，相違するところが多いようである。

カンボジアはプノンペンとその周辺, 西北部のシェ ムリアップやアンコール付近は観光地として, 開発が 進み食に関しての報告も幾つか見られる。しかし，東 北のラタナキリ州については未調査の地域として残さ れていた。2004 年, 10 日間の短い期間であったが, この地方の発酵食品の大豆加工食品と, 伝統を受け継 いでいた粐款吸管の米酒の現状を知り得た。

本調查は一部文部科学省の科学研究費補助金によっ た。またラタナキリ地域の調査のための資料を国立民 族博物館から戴いた。感謝する次第である。

$$
\text { <東京農業大学 名誉教授 }>
$$

付記 小崎道雄先生は平成 18 年 7 月 7 日ご逝去さ れました。謹んでご冥福をお祈りいたします。

(編集部)

\section{文献}

1）小崎道雄, ピーシーサンチェス：「フィリピン の発酵食品」, 食品と容器, 15(2), 66 (1974)

2）小崎道雄, 内村泰：「フィリピン産餅趋ブボッ ドおよび米酒の微生物相」, 醸協, 85(11), 818 (1990)

3) 小崎道雄, 岡田早苗, Erlinda I. Dizon, Priscilla. C. SANCHEZ：「炒り飯の米酒 フィリピ ンのタプイ」, 醸協, 96(10), 705 (2001)

4) 小崎道雄: 「甘蔗酒バシの研究」, 日本伝統研 究会誌, 20, 1 (1999)

5）小崎道雄, 岡田早苗, Erlinda I. Dizon, Priscilla. C. SANCHEZ：「挟み焼きのユニークな米 パン」, 日本伝統食品研究会誌, 23，15（2001）

6）小崎道雄：「東南アジアの発酵食品」, 食の科 学, $144(2), 23$ (1990)

7）飯野久和, Kapti. R. Kuswanto, 岡田早苗, 小崎道雄：「黒ゴマ発酵食品チャブクの微生 物」, 昭和女大大学院生活機構研究科紀要, 6, 107 (1997)

8）小崎道雄, 岡田早苗, 飯野久和：「ラオスの醸 造酒（ラオ八イ）と蒸留酒（ラオラオ）」, 䁔協, 95(3)，193（2000）

9）小崎道雄, 飯野久和, 松本孝, T. L. THUOC: 「ベトナムの吸管酒 ルオウカンの製法と背 景」, 伝統食品食品研究会誌, 21, 17 (2000)

10）小崎道雄：「カンボジアの塩辛ープラホック 一」, 食品保蔵科学会誌, 28(3), 139 (2002)

11）吉田よし子：「世界のユニークな伝統的発酵食 品」, Ajico News, 204, 9 (2002)

12）地球の歩き方編集室：「アンコールワットとカ ンボジア'05〜'06 判」, 258 (2005)

13）田中静一, 小川久恵, 西沢治彦 編著：「中国 植物辞典」(洪光住 監修), 438(1991), 柴田 書店

14）小崎道雄：「ヤシの樹液を採取するとき一吒く か挟むかまたは摇するか一」, 伝統食品の研究, 25, 17 (2003)

15）小崎道雄, 内藤敦, 高山卓美：醸協, 100 (11), 796 (2005) 